\title{
Studies of Liver Insulin Receptors in Non-Obese and Obese Human Subjects
}

\author{
Peter Arner, Kurt Einarsson, Lars Backman, and Klaes Nilsell, Departments \\ of Medicine and Surgery, Huddinge Hospital, and Department of Surgery, \\ Danderyd's Hospital, Stockholm, Sweden S-14186
}

\author{
Kenneth M. Lerea and James N. Livingston, Department of Medicine, \\ University of Rochester, School of Medicine and Dentistry, \\ Rochester, New York, 14627
}

A в S T R A C T The insulin-binding isotherms and the structural composition of human liver insulin receptors were examined by using plasma membranes that were prepared from liver biopsies of nine non-obese and 10 obese subjects undergoing elective surgery. The insulinbinding characteristics of liver membranes from nonobese subjects were quite similar to those previously described in rat liver membranes. However, when the membranes from obese subjects were compared with the non-obese group, insulin-binding activity was reduced by $50 \%(P<0.01)$. The reduction in obesity resulted primarily from a decrease in total receptor number, although a small decrease in receptor affinity was also observed. Insulin binding was not correlated with sex or with the fasting plasma insulin level.

The insulin-binding sites of liver membranes were affinity-labeled with ${ }^{125}$ I-insulin and the cross-linking reagent, disuccinimidyl suberate. The liver membranes from both the non-obese and the obese group had heterogenous (nonreduced) insulin-binding species of $300,000,260,000$, and $150,000 \mathrm{~mol} \mathrm{wt}$, which were again comparable to the findings reported in rat liver. Sulfhydryl reduction demonstrated a major subunit of 125,000 and a minor component of 40,00045,000 in both groups.

These results indicate a close similarity between the hepatic insulin receptor of man and the more intensely

Dr. Livingston is a recipient of the National Institutes of Health Research Career Development Award AM 00470. Address all correspondence to Dr. Arner.

Received for publication 16 March 1983 and in revised form 28 June 1983. studied rat hepatic receptor. Obesity in human subjects is associated with a loss of hepatic insulin receptors. This alteration may contribute to the insulin resistance reported in this organ as well as to obesity-mediated glucose tolerance.

\section{INTRODUCTION}

Binding of insulin to a specific cell surface receptor is the first step in insulin action (1). Because the receptor occupies this central position, it has attracted a large amount of attention not only in studies of insulin action, but also in investigations that have attempted to explain the pathogenesis of insulin-resistant states, like obesity (2). In the human, studies of the insulin receptor have focused primarily on circulating cells (e.g., monocytes and erythrocytes) $(3,4)$ and secondarily on the receptors of adipocytes (5), placenta (6), and fibroblasts (7). In contrast, no information regarding any aspect of the insulin receptor in adult human liver is available. This organ, unlike monocytes and erythrocytes, is a principal target tissue for insulin; consequently, alterations in receptor function may produce serious disturbances in metabolism.

In the present work, we have examined the insulinbinding properties and the structural characteristics of the hepatic insulin receptor of adult non-obese and obese subjects. The results of these studies indicate many similarities between the hepatic human insulin receptor and the receptor in animal tissues. Furthermore, obesity was associated with a marked decrease in total insulin binding activity, which is an alteration that may contribute to the hepatic insulin resistance reported in this metabolic disorder (8). 


\section{METHODS}

Material. Dextran 500 was purchased from Pharmacia Fine Chemicals (Piscataway, NJ) and polyethylene glycol was obtained from Matheson, Coleman, \& Bell (East Rutherford, NJ). New England Nuclear (Boston, MA) supplied carrier-free $\mathrm{Na}^{125} \mathrm{I}$ (high concentration). Acrylamide, $N, N^{\prime}$ methylenebisacrylamide, and $N, N, N^{\prime}, N^{\prime}$-tetramethylethylenediamine were purchased from Eastman Kodak Co. (Rochester, NY). Sodium dodecyl sulfate (SDS), phenylmethylsulfonylfluoride, ovomucoid, and adenosine monophosphate were supplied by Sigma Chemical Co. (St. Louis, MO). Coomassie Blue R-250 and high molecular weight standards ( $M_{r}$ range 200,000-45,000) for reducing gels were obtained from Bio-Rad Laboratories, Richmond, CA. High molecular weight cross-linked standards $\left(M_{r}\right.$ range $\left.336,000-56,000\right)$ for nonreducing gels were purchased from BDH Chemicals Ltd., Poole, England. Pierce Chemical Co., Rockford, IL, supplied disuccinimidyl suberate. Crystalline porcine insulin was a gift from Eli Lilly \& Co., Indianapolis, IN.

Human subjects. Nine non-obese subjects (five males and four females) and 10 obese females were studied. The nonobese subjects had uncomplicated gallstone disease, but were otherwise healthy and were admitted for elective cholecystectomy. They had not been on any special diets to help control gallstone formation. The obese subjects were otherwise healthy and were admitted for gastric operations for obesity. All subjects had maintained constant body weight during the months preceding admittance, and none was on any specific treatment. These subjects had not been treated with drugs that affect liver or carbohydrate metabolism for at least 2 mo before these studies. Four non-obese and six obese subjects were studied in detail and their clinical data are given in Table $\mathbf{I}$.

One of the obese subjects had slightly elevated aminotransferase levels, whereas the others' liver function tests were normal. Morphological evidence of slight fatty infiltration was seen in operative liver biopsies in all of the obese and two of the non-obese subjects, but no other histological abnormalities were observed.

Experimental protocol. An oral 100-g glucose load was given at the Outpatient Department after an overnight fast. The levels of blood glucose (9) and plasma immunoreactive insulin (10) were measured at $-5,15,35,45,60,90$, and 120 min. 2-3 d before the liver biopsy, all subjects were admitted to the Surgical Department as inpatients. During that period, they remained active at approximately their prehospitalization exercise level and they were given an isocaloric weight maintaining diet (30 kcal/ $\mathrm{kg}$ per 24 hours; $45 \%$ carbohydrate, $20 \%$ protein, and $35 \%$ fat). At 8-9 a.m., after an overnight fast, general anesthesia was induced with a short-acting barbiturate and maintained by phentanyl and a nitrous oxide-oxygen mixture. After opening the abdomen, a 1-2-g liver biopsy was obtained from the left lobe of the liver. Only saline was given intravenously before the liver biopsy. The biopsy was placed in ice-cold buffer and immediately transported to the laboratory for the isolation of the liver plasma membranes.

The study was approved by the Ethical Committee of the Karolinska Institute. The subjects were each given a detailed description of the study and their informed consents were obtained.

Preparation of liver plasma membranes. The liver biopsy was homogenized in $50 \mathrm{ml}$ of a $1 \mathrm{mM} \mathrm{NaHCO}$ buffer, $\mathrm{pH}$ 7.5 , containing $0.5 \mathrm{mM} \mathrm{CaCl} 2$ and the plasma membranes isolated by the aqueous two-phase polymer method of Lesko et al. (11). After the membranes had been isolated, they were suspended in a $0.25 \mathrm{M}$ sucrose, $10 \mathrm{mM}$ Tris buffer, $\mathrm{pH} 7.4$, and kept at $-80^{\circ} \mathrm{C}$. The frozen membranes were transported to the University of Rochester in dry ice for studies of insulin binding and receptor structure.

Insulin binding to liver plasma membranes. Insulinbinding activity was measured as described previously for rat liver plasma membranes (12). Approximately $21 \mu \mathrm{g}$ of membrane protein was incubated in $350 \mu$ l of a Krebs-Ringer phosphate buffer, pH 7.4. It contained $3 \%$ bovine albumin. ${ }^{125} \mathrm{I}$-insulin $(0.6 \mathrm{ng} / \mathrm{ml})$ was added with the indicated concentration of native insulin $(2.5-5,000 \mathrm{ng} / \mathrm{ml})$ and the incubation continued for $2 \mathrm{~h}$ at $21^{\circ} \mathrm{C}$. Preliminary studies demonstrated that steady state binding of ${ }^{125} \mathrm{I}$-insulin was reached under these conditions and that the binding activity was proportional to the membrane concentration. The membranes were isolated from the incubation mixture by the centrifugation method of Rodbell et al. (13). As estimated by trichloroacetic acid precipitation (12), insulin degradation was $<10 \%$. Membrane protein was measured as previously described (14) and 5'-nucleotidase activity was estimated as reported by Aronson and Touster (15).

Affinity labeling of the insulin receptor with ${ }^{125}$ I-insulin. The membranes $(\sim 100 \mathrm{~g}$ protein $/ \mathrm{ml})$ were incubated with ${ }^{125} \mathrm{I}$-insulin $\left(5 \times 10^{-10} \mathrm{M}\right)$ in the presence or absence of 5 $\mu \mathrm{g} / \mathrm{ml}$ native hormone in the Krebs-Ringer phosphate buffer, $\mathrm{pH} 7.4$, that contained $3 \%$ albumin and $1 \mathrm{mg} / \mathrm{ml}$ bacitracin. The incubation was conducted for $2 \mathrm{~h}$ at $21^{\circ} \mathrm{C}$ and the crosslinking reagent disuccinimidyl suberate $(1 \mathrm{mM}$, final concentration) was added (16). After $5 \mathrm{~min}$ at $21^{\circ} \mathrm{C}$, the crosslinking reaction was terminated by the addition of $10 \mathrm{mM}$ Tris-HCl, $\mathrm{pH} 7.6$, and $1 \mathrm{mM}$ EDTA (final concentration). The membranes were isolated from the incubation mixture by centrifugation $(10,000 \mathrm{~g}$ for $3 \mathrm{~min}$ ) and prepared for SDSpolyacrylamide gel electrophoresis.

In studies of the nonreduced insulin receptor, the membrane pellets were solubilized in $1 \%$ SDS, $10 \mathrm{mM}$ sodium phosphate buffer, $\mathrm{pH} 7.0$, in the absence of a reducing reagent. The solubilized affinity-labeled material was then subjected to electrophoresis in a 3.3\% SDS acrylamide gel as described by Weber et al. (17). In studies of the reduced insulin receptor, the membranes were solubilized in a buffer that contained 1.8\% SDS, $40 \mathrm{mM}$ Tris- $\mathrm{HCl}, \mathrm{pH} \mathrm{6.8,} \mathrm{and} 50 \mathrm{mM}$ 2-mercaptoethanol. The solubilized material was then subjected to SDS electrophoresis in a $7.5 \%$ acrylamide resolving gel and a $4.5 \%$ acrylamide stacking gel as described by Laemmli (18). After electrophoresis, the gels were fixed in $10 \%$ trichloroacetic acid for $\mathrm{l} \mathrm{h}$, stained with Coomassie Blue R-250, destained, and dried. The gels were exposed to preflashed $X$ Omatic film by using X-Omatic intensifying screens.

Statistical analysis. The values presented are mean $\pm S E$. A computerized program for analysis of variance (19) was used for an evaluation of statistical significance of differences between curves. The calculations were done on a Compucor $\mathrm{p}^{\mathrm{R}}$ desk calculator (Computer Design Corporation, Los Angeles, CA). Statistical difference between the two groups of values was tested using unpaired $t$ test.

\section{RESULTS}

The presence of insulin resistance in the obese subjects described in Table 1 was demonstrated by giving a 100 -g oral glucose load. When compared with the nonobese subjects, the obese group displayed significantly higher blood glucose and plasma insulin values over 
TABLE I

Clinical Data of Four Non-obese and Six Obese Subjects

\begin{tabular}{|c|c|c|c|c|c|c|c|}
\hline Subjects & Sex & Age & Height & Weight & $\begin{array}{l}\text { Fasting } \\
\text { blood } \\
\text { glucose }\end{array}$ & $\begin{array}{l}\text { Fasting } \\
\text { plasma } \\
\text { insulin }\end{array}$ & $\begin{array}{l}\text { Time of } \\
\text { onset of } \\
\text { obesity }\end{array}$ \\
\hline & & $y r$ & $\mathrm{~cm}$ & $k g$ & $\mathrm{mmol} / \mathrm{l}$ & $\mu U / m l$ & \\
\hline \multicolumn{8}{|l|}{ Non-obese } \\
\hline 1 & $\mathbf{M}$ & 58 & 174 & 69 & 5.2 & 7.1 & \\
\hline 2 & $\mathbf{M}$ & 44 & 187 & 78 & 5.1 & 3.2 & \\
\hline 3 & $\mathbf{F}$ & 48 & 167 & 62 & 5.1 & 8.9 & \\
\hline 4 & $\mathbf{F}$ & 42 & 164 & 60 & 4.1 & 2.3 & \\
\hline Mean $\pm S E$ & & $48 \pm 4$ & $173 \pm 5$ & $67 \pm 4$ & $4.9 \pm 0.3$ & $4.9 \pm 1.9$ & \\
\hline \multicolumn{8}{|l|}{ Obese } \\
\hline 5 & $\mathbf{F}$ & 34 & 153 & 105 & 4.7 & 10.7 & $\mathbf{x}$ \\
\hline 6 & $\mathbf{F}$ & 34 & 168 & 113 & 4.3 & 8.0 & $\mathbf{x x}$ \\
\hline 7 & $\mathbf{F}$ & 30 & 169 & 130 & 5.6 & 30.7 & $\mathbf{x}$ \\
\hline 8 & $\mathbf{F}$ & 55 & 163 & 115 & 5.3 & 29.6 & $\mathbf{x x}$ \\
\hline 9 & $\mathbf{F}$ & 47 & 155 & 107 & 5.3 & 38.1 & $\mathbf{x x}$ \\
\hline 10 & $\mathbf{F}$ & 40 & 162 & 83 & 5.6 & 22.4 & $\mathbf{x}$ \\
\hline Mean $\pm S E$ & & $40 \pm 4$ & $162 \pm 3$ & $109 \pm 6$ & $5.1 \pm 0.6$ & $23.3 \pm 4.9$ & \\
\hline
\end{tabular}

$\mathrm{x}$, postadolescence; $\mathrm{xx}$, preadolescence.

a 2-h period (Fig. 1). However, none of the obese subjects was glucose intolerant.

Hepatic plasma membranes were isolated from liver biopsies of these subjects. In these studies, the twophase polymer technique was used for membrane isolation because it provided a much better yield than other methods. The degree of purification, based on 5 '-nucleotidase activity, indicated a $7.9 \pm 0.6$ - and a $7.1 \pm 0.7$-fold enrichment (mean \pm SE) over the homogenate value for non-obese and obese subjects, respectively. The specific activities of 5 -nucleotidase in the plasma membranes were $65 \pm 10$ and $81 \pm 5 \mathrm{nmol}$ phosphate released $/ \mathrm{mg}$ protein per minute (mean $\pm \mathrm{SE}$ ), respectively, for non-obese and obese. The specific activity of $5^{\prime}$-nucleotides is lower in these membranes than that reported for rhesus monkey liver membranes (20), which may indicate a species difference or that activity is lost after membrane freezing. In any case, the degree of purification of liver plasma membranes from non-obese and obese liver is similar.

Because of the small amounts of human tissue available, it was not possible to study many of the insulinbinding properties described in animal tissues (e.g., pH optima, dissociation rates, negative cooperativity, etc.) However, the binding of insulin by membranes from non-obese subjects displayed characteristics similar to those reported for rat liver membranes. For example, the time required for binding to reach steady state at $21^{\circ} \mathrm{C}$ was $\sim 90-120$ min (data not shown).
Furthermore, Scatchard analysis of the insulin-binding data for non-obese subjects, as shown in Fig. 2, indicated a comparable number of binding sites to that reported in rat membranes (12).

Steady state insulin binding was simultaneously determined in the liver membranes from obese and nonobese subjects, and the results are compared in Fig. 2. Competition curves showed a marked decrease in insulin binding in obese subjects as compared with the non-obese subjects over the entire range of insulin concentrations tested $(\mathrm{F}=35 ; P<0.01)$. The value for bound $/$ free $(\mathrm{B} / \mathrm{F}) \times 10^{3}$ at a tracer insulin concentration was $26.1 \pm 3.9$ for the non-obese group and $14.5 \pm 2.6$ for the obese subjects $(P<0.05)$. Transformation of the binding data according to Scatchard (21) yielded two nonlinear plots that were almost parallel with a large difference in their abscissa intercepts. Although it is recognized that determining total receptor number from a curvilinear Scatchard plot is highly inaccurate (22), the parallel decrease in binding throughout the curve supports a loss in total insulin-binding sites. Based on these curves, the maximum binding capacity $\left(\mathrm{B}_{0}{ }^{1}\right.$; nanograms of insulin per $21 \mu \mathrm{g}$ protein $\times 10^{2}$ ) was $53 \pm 7$ for the non-obese group and $28 \pm 7$ for the obese group $(P<0.05)$.

\footnotetext{
${ }^{1}$ Abbreviations used in this paper: $\mathrm{B}_{0}$, maximum binding capacity.
} 

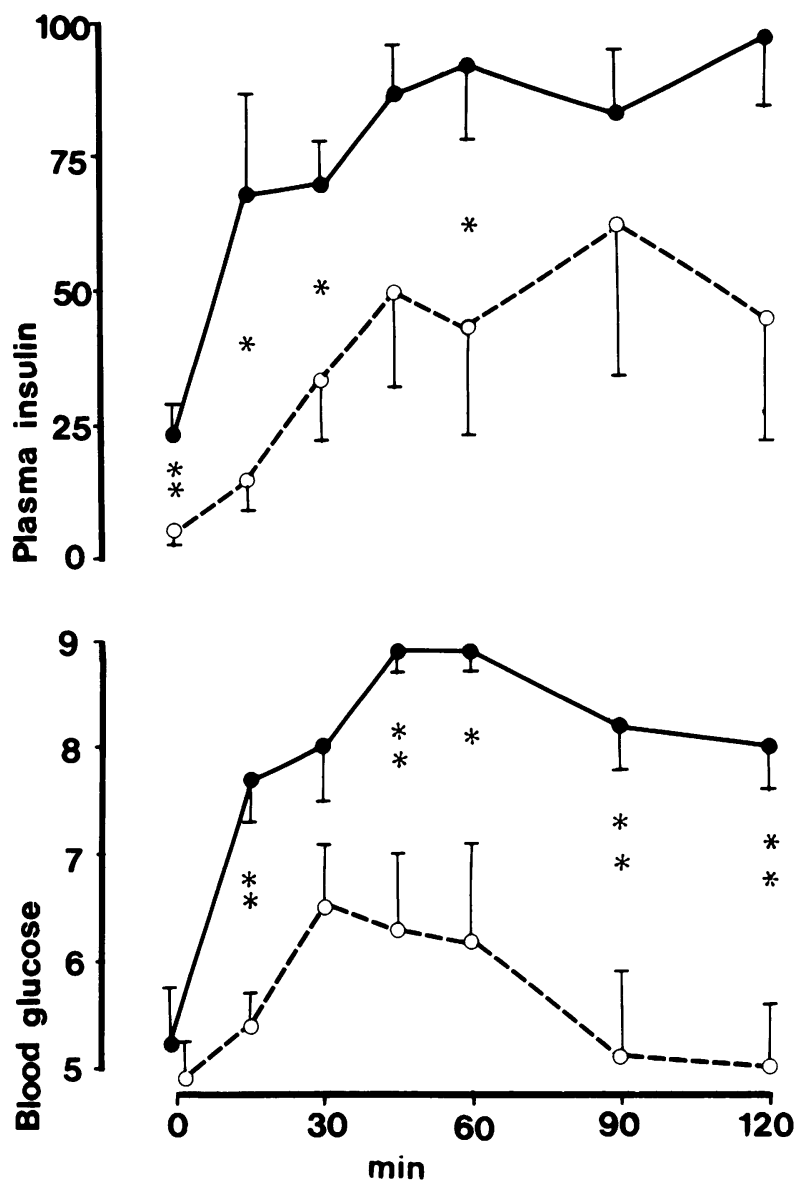

FigURE 1 Results of oral glucose tolerance tests in non-obese (O) and obese (O) subjects. Non-obese subjects and obese subjects described in Table I were given a $100-\mathrm{g}$ oral glucose load and plasma insulin (milliunits/liter) and blood glucose (millimoles/liter) were followed for $120 \mathrm{~min}$. Data are mean $\pm S E$. Unpaired $t$ test was used for statistical evaluation. $*, P<0.05 ; * *, P<0.01$.

In order to examine receptor affinity, the binding data were transformed to insulin displacement curves (Fig. $2 \mathrm{C}$ ). There was a statistical difference between mean curves for the obese and non-obese groups $(F=$ $8 ; P<0.05)$ in the range of insulin concentrations from 2.5 to $50 \mathrm{ng} / \mathrm{ml}$. The concentration of native insulin required to reduce ${ }^{125} \mathrm{I}$-insulin binding by $50 \%\left(\mathrm{~B}_{50}\right)$ was $27 \mathrm{ng} / \mathrm{ml}$ in the non-obese group and $40 \mathrm{ng} / \mathrm{ml}$ in the obese group.

It is possible that sex differences contribute to these results because obese female subjects were compared with non-obese individuals of both sexes. The possible influence of sex on insulin binding was examined by using plasma membranes from two male and two female non-obese subjects, as described in Table I. As shown in Fig. 3, Scatchard analysis of the binding data indicated no major influence of sex on the insulin-binding characteristics of the plasma membranes.

The insulin-binding properties of the membranes from both groups were also compared with the subjects' fasting insulin levels. This comparison failed to show any correlation of fasting insulin level with the values for $\mathrm{B} / \mathrm{F}, \mathrm{B}_{0}$, or $\mathrm{B}_{50}(r<0.4)$, by using data from 10 simultaneously performed binding experiments.

The structure of the human insulin receptor was examined by SDS polyacrylamide electrophoresis after ${ }^{125}$ I-insulin was covalently attached with the cross-linking reagent, disuccinimidyl suberate (16). This method was chosen because it allows the insulin-binding sites to be labeled by ${ }^{125}$ I-insulin in situ with a reasonable degree of efficiency. Fig. 4 shows an autoradiogram of the nonreduced insulin-binding species from human liver membranes. The plasma membranes from a nonobese male, a non-obese female, and two obese females all contain very similar insulin binding species, e.g., a 300,000 , a 260,000 , and a 150,000 species. In these gels, a small amount of higher molecular weight binding activity is also evident. This pattern of heterogenous species is very similar to the pattern found in rat liver membranes (23), which further supports the suggestion made above that the hepatic insulin receptors of man and rat are alike in many or most aspects.

Fig. 5 illustrates the subunit composition of the insulin receptors from these subjects. The major subunit labeled by the cross-linking reagent is a $125,000 \mathrm{com}$ ponent. In all the membranes examined, a minor 40,000-45,000 species was detected. In addition, some specific insulin labeling of material that ran in a broad band below the 125,000 subunit was evident. It is possible that this material corresponds to the 95,000 receptor subunit labeled by photoaffinity methods in rat liver membranes (24); it is a subunit that is not labeled with any degree of efficiency by the cross-linking reagent.

In all of the studies of receptor structure, no difference was observed between the obese and non-obese groups. The changies in hormone binding in obesity evidently arise therefore from a primary decrease in the number of receptors rather than any major structural alterations. Likewise, the small change in binding affinity could not be explained by these structural studies. It is possible that alterations in the membrane environment could influence the binding affinity (25), or that SDS electrophoresis doesn't provide the necessary discrimination needed to detect subtle structural or conformational changes that are involved in affinity regulation.

In some experiments, various protease inhibitors were added during the isolation of liver membranes. This did not change the proportions of the binding species that are described above. 

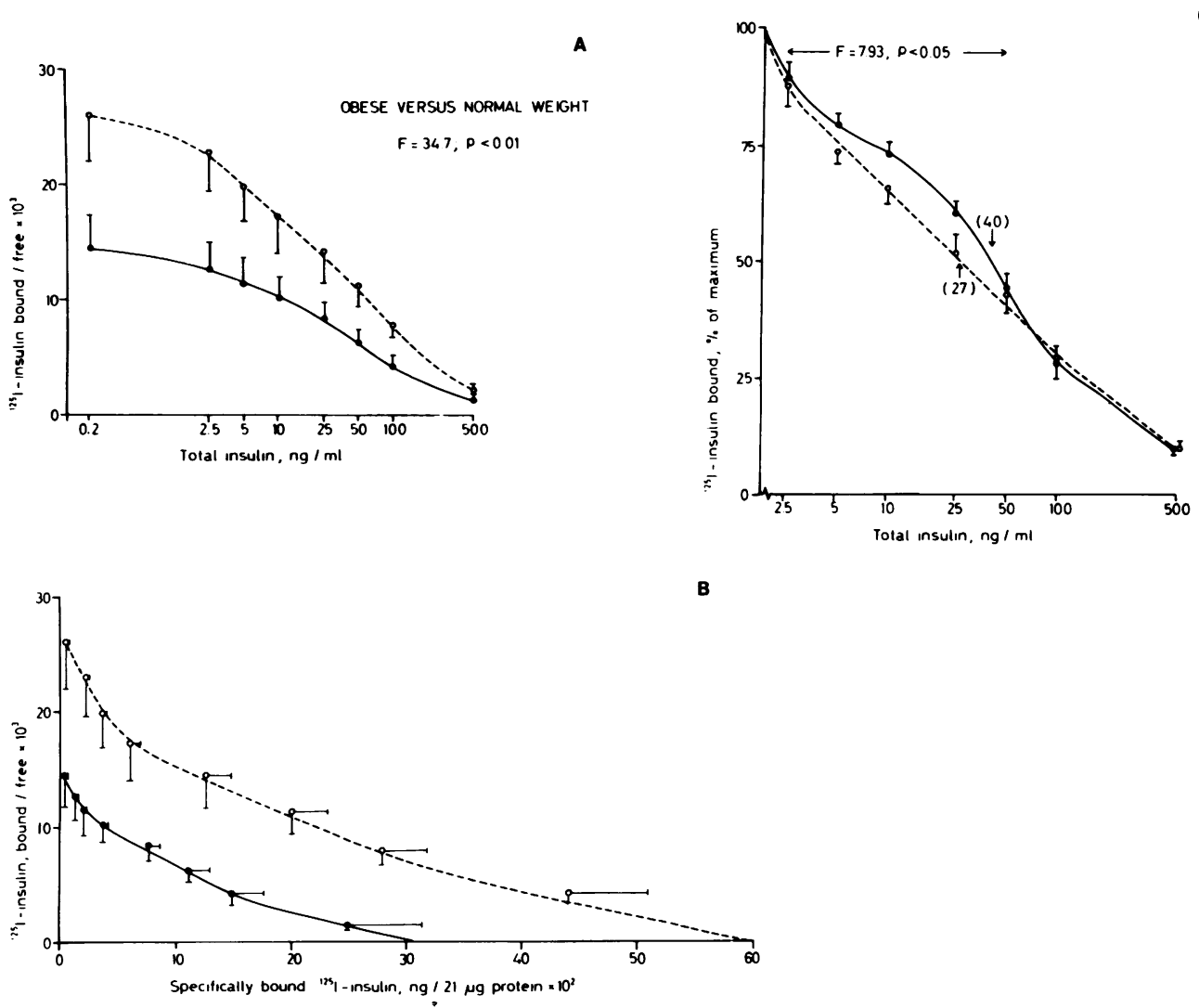

FIgURE 2 Steady state-specific ${ }^{125}$ I-insulin binding to purified liver membranes from non-obese $(O)$ and obese (O) subjects. Data represents the subjects in Table I. (A) Competition plot. (B) Scatchard plot. $(C)$ Percent inhibition of ${ }^{125} \mathrm{I}$-insulin binding. Statistical difference between curves was tested using analysis of variance. Binding was simultaneously determined in all membranes. The binding data are expressed per total amount of membrane protein which was $21 \mu \mathrm{g}$ in each assay.

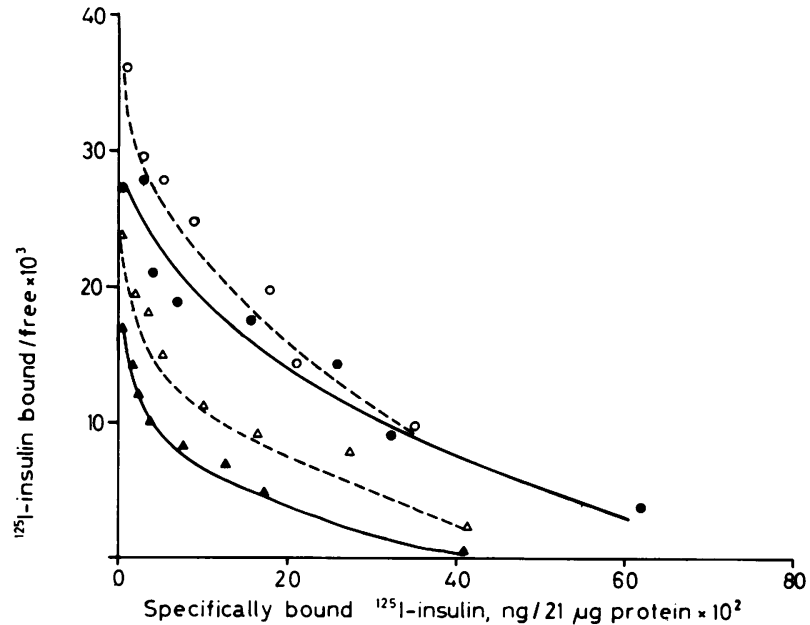

FIgURE 3 Influence of sex on specific ${ }^{125} \mathrm{I}$-insulin binding to human plasma membranes. The individual Scatchard curves, obtained with two female (open symbols, broken lines) and two male (solid symbols, solid lines) non-obese subjects described in Table I are presented. Binding was simultaneously determined in all subjects.
Six obese subjects were investigated in detail (Table I). The onset of obesity occurred in childhood in three subjects and later in the remaining half of the subjects. Their individual Scatchard plots were compared in order to investigate the influence of the time of the onset of obesity on the insulin-binding properties of the liver membranes. However, no major difference between childhood and adult obesity was observed.

\section{DISCUSSION}

Previous studies of the human insulin receptor in liver have been limited to the fetus (26) and to a case report in which postmortem tissue from two infants were examined for insulin-binding activity (27). The present report describes the insulin-binding characteristics of adult human liver membranes from normal and obese subjects, and certain structural features of the human hepatic insulin receptor.

The overall insulin-binding properties of liver membranes from normal subjects did not differ in any sig- 


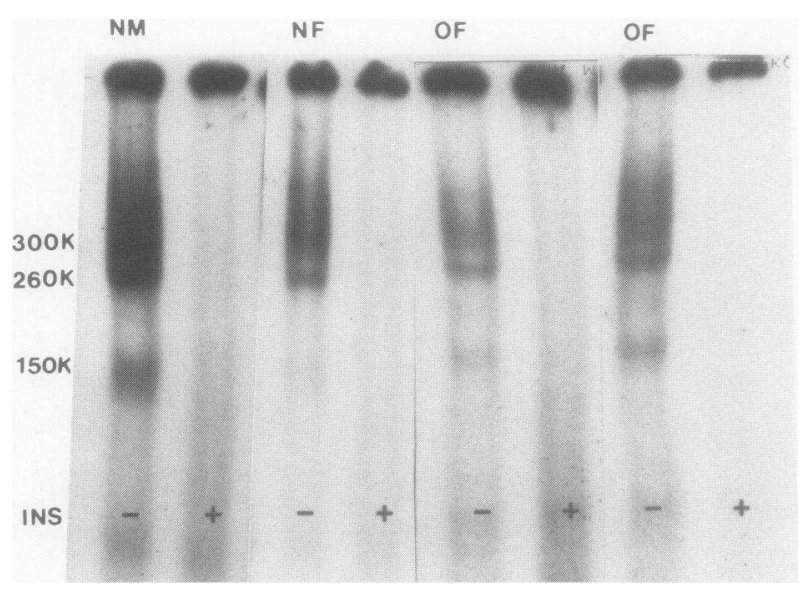

Figure 4 Autoradiogram of nonreduced insulin receptors of human liver membranes. Liver membranes from a normal male $(N M)$, a normal female (NF), and two obese females $(O F)$ were affinity labeled with ${ }^{125} \mathrm{I}$-insulin in the absence (-ins) or presence (+ins) of $5 \mu \mathrm{g} / \mathrm{ml}$ native insulin as described in Methods. After labeling, the membranes were prepared for SDS electrophoresis in a $3.3 \%$ polyacrylamide gel. Lane $N M$ was overexposed to show the labeling of 150,000 species.

nificant respect from insulin binding by rat liver membranes (12), although the number of different types of studies that could be conducted were limited by the small amount of human membranes. Thus, maximum insulin binding, as derived from Scatchard analysis of the binding data, was similar to the amount bound by rat liver membranes (12). Also, the Scatchard plot was curvilinear and the overall binding affinity, as defined by the insulin displacement curve, was similar to those of liver membranes from rats (12) and from normal rhesus monkeys (20). Furthermore, treatment of human liver membranes with wheat germ agglutinin produced a marked increase in specific insulin-binding activity. This effect is found in the receptor of rat adipocytes and liver, but not in the receptor of human monocytes (12). These findings with wheat germ agglutinin demonstrate further that the hepatic insulin receptors in rat and man are similar; also, they suggest that a difference exists between the human hepatic receptor and the receptor on circulating monocytes.

Insulin-binding studies were also conducted with liver membranes from obese subjects. When the results with obese and non-obese subjects were compared, a marked decrease in specific insulin binding to liver membranes was observed in obesity. This alteration was largely caused by a reduction in the maximum binding capacity as indicated by a $50 \%$ decrease in the $B_{0}$ value from the non-obese value. Also, a small but statistically significant decrease in the insulin-binding affinity was evident when the insulin competition curves for the two groups were compared (Fig. $2 \mathrm{C}$ ). It is possible that this small change in affinity contributes to the reduction in binding, particularly at physiologic insulin concentrations; however, the predominant alteration in obesity is clearly the decrease in receptor number.

It is not likely that the differences in insulin binding to membranes from obese and non-obese subjects are due to methodological variations or clinical differences other than obesity. Insulin binding was simultaneously determined in membranes from all subjects and recovery of plasma membrane protein was similar for both groups. Furthermore, there was neither significant age differences nor major differences in liver histology. Finally, in these studies, the sex of the subject did not influence insulin binding by the liver membranes.

Previous studies of obesity have used circulating monocytes (28-33), erythrocytes (30), and adipocytes $(5,33-36)$ to determine the status of the human insulin receptor. When insulin binding is expressed on a per cell basis, certain of these studies have reported a reduction in binding (28-30, 33-35) whereas others have found little or no change in binding activity $(5,31,32$, 36 ). In view of these differences and for other reasons, it has been postulated that the metabolic abnormalities in human obesity are heterogenous and that the site(s) of the alteration responsible for the disorder may vary (37). For example, evidence has been presented that the insulin resistance in obese peripheral tissue results in part from a postbinding defect (38).

The status of the liver insulin receptor in human obesity has not been previously determined, although

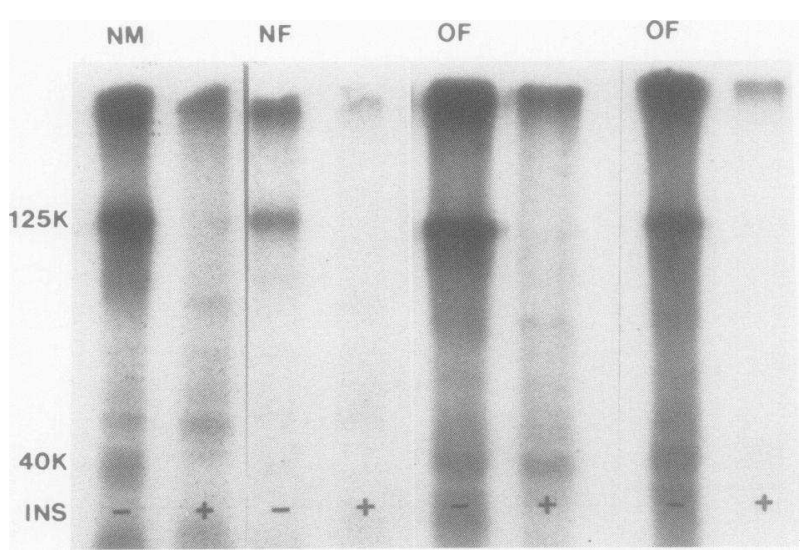

Figure 5 Autoradiogram of the subunit composition of the sulfhydryl-reduced human insulin receptors. The lane designations are the same as described in Fig. 4. After preparation of the affinity-labeled subunits (see Methods), the subunits were subjected to SDS electrophoresis in a $7.5 \%$ acrylamide resolving gel. 
clear evidence of a reduction in the numbers of this receptor has been reported in genetically obese rodents (39). In the one study of the hepatic receptor (20) in a primate (rhesus monkey) animal model for spontaneous obesity, the number of hepatic insulin receptors was reduced to the same extent as that found in our studies of the obese human liver. Thus, unlike the situation in peripheral tissues, all of the results that have been reported thus far argue that a reduction in hepatic insulin receptors occurs in obesity.

In instances of diminished insulin binding, it has been suggested that the receptor number is "downregulated" by the elevation in circulating insulin concentration (40). However, we found no correlation between fasting insulin levels and insulin binding; this argues against hyperinsulinemia as the only factor responsible for altering the hepatic insulin-binding activity. It is possible that the concentration of insulin in the liver is different from that observed in the blood and that elevated insulin secretion into the portal system in obesity contributes to the loss of hepatic insulin receptors.

The structural characteristics of the hepatic insulin receptor from obese and non-obese subjects were identical, at least as determined by the affinity labeling method of Pilch and Czech (16). SDS electrophoresis of the nonreduced human receptor demonstrated two major high molecular weight species of 300,000 and 260,000 and minor species of 360,000 and 150,000 . The addition of protease inhibitors during membrane isolation did not alter the proportions of these species; others have noted this finding in studies of insulinbinding sites $(41,42)$. Thus, although the different species may arise from protease action, it is more likely to occur in vivo than during membrane preparation or affinity labeling of the receptor.

A major subunit of 125,000 was evident after sulfhydryl reduction. This subunit has been observed in the receptor of rat tissues and human placenta (43). A minor, specifically labeled subunit of 40,000 was usually evident; it also has been reported in rat liver and human placenta (43). Finally, affinity-labeled material that runs in the region of $90-110,000$ was detected. A portion of this material may be the 95,000 subunit that was found in rat liver membranes by the photoaffinity labeling method (24).

These results show that the human liver insulin receptor has structural features and insulin-binding properties that are quite similar to those reported for the receptor in animal tissues. Furthermore, with obesity, there is a loss of insulin receptors; this alteration may contribute to the insulin resistance found in the liver of obese subjects (8). The liver plays a central role in regulating glucose tolerance. The major portion of an oral glucose load is retained by the liver under normal conditions (44). Furthermore, a decrease in glucose tolerance was observed. Thus, it is possible that a reduction in hepatic insulin binding may at least partly explain this abnormality of glucose tolerance.

\section{ACKNOWLEDGMENTS}

The authors are indebted to Lisbet Benthin for her expert technical assistance.

The present study was supported by grants from the Swedish Medical Research Council, the Swedish Medical Association, the Swedish Diabetes Association, the Karolinska Institute, the Foundations of Folksam, Groschinsky, Tore Nilsson and Nordic Insulin, and National Institutes of Health grant AM 25116.

\section{REFERENCES}

1. Roth, J. 1981. Insulin binding to its receptor: is the receptor more important than the hormone? Diabetes Care. 4:27-32.

2. Olefsky, J. M. 1981. Insulin resistance and insulin action. Diabetes. 30:148-162.

3. Gavin, J. R., III, P. Gorden, and J. Roth. 1973. Characterization of the human lymphocyte insulin receptor. J. Biol. Chem. 248:2202-2207.

4. Gambhir, K. K., J. A. Archer, and C. J. Bradley. 1978. Characterization of human erythrocyte insulin receptor. Diabetes. 27:701-708.

5. Amatruda, J. M., J. N. Livingston, and D. H. Lockwood. 1975. Insulin receptor: role in the resistance of human obesity to insulin. Science (Wash. DC). 188:264-266.

6. Harrison, L. C., T. Billington, I. J. East, R. J. Nichols, and S. Clark. 1978. The effect of solubilization on the properties of the insulin receptor of human placental membranes. Endocrinology. 102:1485-1495.

7. Rechler, M. M., and J. M. Podskalny. 1976. Insulin receptors in cultured human fibroblasts. Diabetes. 25:250255.

8. Felig, P., J. Wahren, R. Hendler, and T. Brundin. 1974. Splanchnic glucose and amino acid metabolism in obesity. J. Clin. Invest. 53:582-590.

9. Coburn, H. J., and J. J. Carrol. 1973. Improved manual and automated calorimetric determination of serum glucose with the use of hexokinase and glucose-6-phosphate-dehydrogenase. Clin. Chem. 19:127-130.

10. Wide, L., R. Axen, and J. Porath. 1967. Radioimmunosorbent assay for proteins. Chemical couplings of antibodies to insoluble dextran. Immunochemistry. 4:381386.

11. Lesko, L., M. Donlon, G. V. Marinetti, and J. D. Hare. 1973. A rapid method for the isolation of rat liver plasma membranes using aqueous two-phase polymer system. Biochim. Biophys. Acta. 331:173-179.

12. Pottick, L. A., R. T. Moxley, III, and J. N. Livingston. 1981. Tissue differences in insulin receptors. Diabetes. 30:196-202.

13. Rodbell, M., M. J. Krans, S. L. Pohl, and L. Birnbaumer. 1971. The glucagon-sensitive adenyl cyclase system in plasma membranes of rat liver. J. Biol. Chem. 246:18611871 .

14. Bradford, M. M. 1976. A rapid and sensitive method for the quantitation of microgram quantities of protein using the principle of protein-dye binding. Anal. Biochem. 72:248-253.

15. Aronson, N. N., Jr., and O. Touster. 1974. Isolation of 
rat liver plasma membrane fragments in isotonic sucrose methods. Methods Enzymol. 31:90-102.

16. Pilch, P. F., and M. P. Czech. 1979. Interaction of crosslinking agents with the insulin effector system of isolated fat cells. J. Biol. Chem. 254:3375-3381.

17. Weber, K., J. R. Pringle, and M. Osborn. 1972. Measurement of molecular weights by electrophoresis on SDS-acrylamide gel. Methods Enzymol. 26:3-27.

18. Laemmli, U. K. 1970. Cleavage of structural proteins during the assembly of the head of bacteriophage $T_{4}$. Nature (Lond.). 227:680-685.

19. Kirk, R. E. 1968. Experimental design. In Procedures for the Behavioral Sciences. Wadsworth Publishing Co., Belmont, CA 200-208.

20. Lockwood, D. H., C. L. Hamilton, and J. N. Livingston. 1979. The influence of obesity and diabetes in the monkey on insulin and glucagon binding to liver membranes. Endocrinology. 104:76-81.

21. Scatchard, G. 1949. The attraction of proteins for small molecules and ions. Ann. NY Acad. Sci. 51:660-672.

22. Klotz, I. M. 1982. Numbers of receptor sites from Scatchard graphs: facts and fantasies. Science (Wash. DC). 217:1247-1248.

23. Massague, J., and M. P. Czech. 1980. Multiple redox forms of the insulin receptor in native liver membranes. Diabetes. 29:945-947.

24. Yip, C. C., C. W. T. Yeung, and M. L. Moule. 1980. Photoaffinity labeling of insulin receptor proteins of liver plasma membrane preparations. Biochemistry. 19:7076.

25. Gould, R. J., B. H. Ginsberg, and A. A. Spector. 1982. Lipid effects on the binding properties of a reconstituted insulin receptor. J. Biol. Chem. 257:477-484.

26. Neufeldt, N. D., M. Scott, and S. A. Kaplan. 1980. Ontogenity of the mammalian insulin receptor. Studies of human and rat fetal liver plasma membranes. Dev. Biol. 78:151-160.

27. D'ercole, A., L. E. Underwood, and A. Plet. 1979. Leprechaunism: studies of the relationship among hyperinsulinism, insulin resistance and growth retardation. $J$. Clin. Endocrinol. Metab. 48:495-502.

28. Archer, J. A., P. Groden, and J. Roth. 1975. Defect in insulin binding to receptors in obese man. Amelioration with caloric restriction. J. Clin. Invest. 55:166-174.

29. Bar, R. S., P. Gorden, J. Roth, C. R. Kahn, and P. DeMeyts. 1976. Fluctuations in the affinity and concentration of insulin receptors on circulating monocytes of obese patients. Effects of starvation, refeeding, and dieting. J. Clin. Invest. 58:1123-1135.

30. DePirro, R., A. Fusco, R. Lawes, I. Testa, G. Ferretti, and C. DeMartinis. 1980. Insulin receptors on monocytes and erythrocytes from obese patients. J. Clin. Endocrinol. Metab. 51:1437-1439.
31. Misbin, R. I., A. J. Pulkkinen, and J. P. O'Leary. 1979. Insulin receptors in obesity-a reassessment. Science (Wash. DC). 205:1003-1004.

32. Savage, D. J., R. F. Hamman, and P. H. Bennet. 1979. Prediabetes in the Pima Indians. In Treatment of Early Diabetes. R. A. Camerini-Davalos and B. Hanover, editors. Plenum Press, New York. 13-19.

33. Olefsky, J. M. 1976. Decreased insulin binding to adipocytes and circulating monocytes in obesity. J. Clin. Invest. 57:1165-1172.

34. Kolterman, O. G., G. M. Reaven, and J. M. Olefsky. 1979. Relationship between in vivo insulin resistance and decreased insulin receptors in obese man. J. Clin. Endocrinol. Metab. 48:487-494.

35. Harrison, L. C., F. I. R. Martin, and R. A. Melick. 1976. Correlation between insulin receptor binding in isolated fat cells and insulin sensitivity in obese human subjects. J. Clin. Invest. 58:1435-1441.

36. Smith, U., and M. DeGirolamo. 1980. Binding of insulin to human adipocytes in relation to age, relative body weight, and fat cell size. Clin. Res. 28:406a.

37. Olefsky, J. M., and T. P. Ciaraldi. 1981. The insulin receptor:basic characteristics and its role in insulin resistant states. In Handbook of Diabetes Mellitus. M. Brownlee, editor. Garland Publishing, Inc., New York. 2:73-116.

38. Kolterman, O. G., J. Insel, M. Saekow, and J. M. Olefsky. 1980. Mechanisms of insulin resistance in obesity. Evidence for receptor and postreceptor defects. J. Clin. Invest. 65:1272-1284.

39. Kahn, C. R., D. M. Neville, Jr., and J. Roth. 1973. Insulin receptor interaction in the obese hyperglycemic mouse: a model of insulin resistance. J. Biol. Chem. 248:244250.

40. Gavin, J. R., III, J. Roth, D. M. Neville, Jr., P. DeMeyts, and D. N. Buell. 1974. Insulin-dependent regulation of insulin receptor concentrations: a direct demonstration in cell culture. Proc. Natl. Acad. Sci. USA. 31:84-88.

41. Massague, J., P. F. Pilch, and M. P. Czech. 1981. A unique proteolytic cleavage site on the $\beta$-subunit of the insulin receptor. J. Biol. Chem. 256:3182-3190.

42. Pollet, R. J., E. S. Kempner, M. L. Standaert, and B. A Haase. 1982. Structure of the insulin receptor of the cultured human lymphoblastoid cell IM-9. J. Biol. Chem. 257:894-898.

43. Massague, J., and M. P. Czech. 1981. Structural relationships of the $\alpha$ and $\beta$ insulin receptor subunits. In Current Views on Insulin Receptors. D. Andreani, R. DePirro, R. Lauro, J. M. Olefsky, and J. Roth, editors. Academic Press, New York. 13-22.

44. Felig P., J. Wahren, and R. Hendler. 1975. Influence of oral glucose ingestion on splanchic glucose and gluconeogenic substrate metabolism in man. Diabetes. 24:468475 . 